\title{
The Public SAFETy (PubliC PROTECTION ORDERS) BILL 2012: IS Post-Sentence Detention of SeX OFFENDERS CONSISTENT WITH HUMAN RIGHTS?
}

\section{Jasmin Moran*}

\begin{abstract}
This article examines the human rights consistency of the Public Safety (Public Protection Orders) Bill 2012. The Bill proposes a new scheme to detain recidivist sex offenders beyond the expiration of their finite sentences, if they are seen as highly likely to reoffend. Despite obvious human rights concerns, the Attorney-General issued a statement contending the Bill was consistent with the New Zealand Bill of Rights Act 1990. The article analyses the correctness of that statement, with a particular focus on whether the Bill establishes a form of civil committal and is, in substance, different to prison detention.
\end{abstract}

\section{INTRODUCTION}

On 29 August 2012, New Zealand's most notorious sex offender, Stewart Murray Wilson, the so-called "Beast of Blenheim", was released from prison. ${ }^{1}$ Wilson was convicted in 1996 of a host of heinous offences committed over 25 years, including seven counts of rape and charges of bestiality, indecent assault, ill treatment of children and stupefaction. ${ }^{2}$ Although Heron $\mathrm{J}$ thought preventive detention was appropriate, it could only be imposed in respect of a rape offence occurring after 1 September $1993 .{ }^{3}$ It was not certain Wilson's offending satisfied this requirement

\footnotetext{
* Article submitted as part of the LLB(Hons) programme at Victoria University of Wellington. The author would like to thank Dr Nessa Lynch for her insightful comments.

1 Anne-Marie Everson "'Beast' free, release plan still unclear" The Wanganui Chronicle (online ed, Wanganui, 29 August 2012).

$2 \quad R v$ Wilson HC Wellington T-104-95, 15 March 1996 at 1-2.

$3 \quad R v$ Wilson, above n 2, at 6-7.
} 
and Heron $\mathrm{J}$ was forced to impose a finite sentence of 21 years. ${ }^{4}$ When Wilson's final release date approached, he had to be released, despite being assessed as highly likely to sexually reoffend and having been repeatedly denied parole on that basis. ${ }^{5}$ Wilson was released subject to various conditions imposed by the Parole Board until 2015 and from thereafter, an extended supervision order (ESO). ${ }^{6}$

Wilson, and other similar offenders, who are not sentenced to preventive detention, but who are evaluated as overwhelmingly likely to sexually reoffend at the end of their sentences, present a quandary for the New Zealand justice system. Under the status quo, these offenders must be released and may be subject to similar restrictions as Wilson received. However, these restrictions are seen by some as insufficient to protect the public from the serious harm posed by such offenders. To combat this perceived public safety issue, the National-led Government introduced the Public Safety (Public Protection Orders) Bill (the Bill), to Parliament on 18 September 2012. ${ }^{7}$ The Bill would enable the High Court to make a public protection order (PPO) detaining an individual who has completed their finite sentence but poses a very high risk of reoffending. At the time of writing, the Bill was before the Justice and Electoral Committee having passed its first reading by a vote of 106-14. ${ }^{8}$ This article was concluded before the release of the Justice and Electoral Committee's report in April 2014.

While there are sound policy reasons for the Bill, namely public protection, it raises serious human rights issues with regards to the New Zealand Bill of Rights Act 1990 (NZBORA). The National-led Government and the Attorney-General, the Hon Christopher Finlayson MP, have both issued statements to the effect that the Bill is NZBORA compliant. ${ }^{9}$ The purpose of this paper is to test the veracity of this claim.

This discussion will proceed in three parts. First, the conceptual foundations of the Bill, penal populism and public attitudes towards sex offenders, will be discussed. Secondly, the New Zealand case law and sources related to the human rights consistency of the Bill with NZBORA will be

4 At 6 .

5 New Zealand Parole Board Wilson - Stewart Murray - Review of s 107 order Under s 107(6) of the Parole Act 2002 (29 April 2011); New Zealand Parole Board Wilson - Stewart Murray - Review of s 107 order Under s 107(6) of the Parole Act 2002 (17 October 2011); New Zealand Parole Board Wilson - Stewart Murray - Parole hearing Under s 107(6) of the Parole Act 2002 (30 March 2012).

6 New Zealand Parole Board Wilson - Stewart Murray - Parole hearing Under s 104(FRD) of the Parole Act 2002 (7 August 2012).

7 Public Safety (Public Protection Orders) Bill 2012 (68-1) [Public Safety Bill].

8 The Green Party and Mana voted against the Bill. See (18 September 2013) 693 NZPD 13480.

9 Christopher Finlayson Public Safety (Public Protection Orders) Bill - Consistency with the New Zealand Bill of Rights Act 1990 (14 October 2012); New Zealand Government "Q+A - Public Safety (Public Protection Orders) Bill" (press release, 18 September 2012). 
analysed. These sources will then be compared to case law from the United States and Australia, both of which have similar post-sentence detention schemes for sex offenders. The conclusion reached is that while the Bill does pose human rights concerns, it achieves an appropriate balance between human rights and public protection.

\section{THE PUBLIC SAFETY (PUBLIC PROTECTION ORDERS)} BILL 2012

\section{A Purpose of the Bill}

The Bill is framed in terms of public protection rather than punishment. The Bill explicitly disclaims that its objective is to punish former offenders. ${ }^{10}$ Instead, the established purpose is to protect the public from almost certain serious sexual or violent harm. ${ }^{11}$ A Government press release emphasises this point, stating, "[d]etention would be protective rather than punitive": "PPOs are... not criminal punishments". ${ }^{12}$ As such, one of the principles included in the Bill is that individuals subject to a PPO should have "as much autonomy and quality of life as possible". ${ }^{13}$

\section{$B$ Requirements for the Imposition of a PPO}

To be eligible for a PPO, an individual must be 18 years or older, detained under a determinate sentence for a serious sexual or violent offence and be within six months of his or her release. ${ }^{14}$ An individual subject to the most serious form of an ESO is also eligible. ${ }^{15}$ The Chief Executive of the Department of Corrections can apply to the High Court for a PPO in respect of such individuals if there is a high risk of imminent serious sexual or violent offending. ${ }^{16}$ In the application, the Chief Executive must include at least two reports prepared by health assessors, including a registered psychologist, that address whether such a risk exists and whether the individual exhibits a high level of four behavioural characteristics. ${ }^{17}$ These characteristics are specified in cl 13 as:

(a) an intense urge to commit a particular form of offending;

(b) limited self-regulatory capacity, evidenced by general impulsiveness, high emotional reactivity, and inability to cope with, or manage, stress and difficulties;

10 Public Safety Bill, cl 4.

11 Clause 4. See also Public Safety Bill (explanatory note) at 1.

12 New Zealand Government, above n 9, at 2 and 4.

13 Clause 5.

14 Clause 7.

15 Clause 7.

16 Clause 8.

17 Clause 9. 
(c) absence of understanding or concern for the impact of offending on actual or potential victims; and

(d) poor interpersonal relationships or social isolation or both. ${ }^{18}$

The High Court can issue a PPO if satisfied the individual meets the threshold and there is a very high risk of imminent serious sexual or violent offending. ${ }^{19}$ To do this, the Court must find the individual exhibits a severe disturbance in behavioural functioning, established by a high level of the above four characteristics. ${ }^{20}$

Once issued, a review panel established under the Bill must frequently review a PPO. ${ }^{21}$ Additionally, within the first five years of a PPO, the Court must review the continuing justification for the order, including the individual's eligibility for release. ${ }^{22}$ An individual subject to a PPO can apply to the Court to conduct such a review. ${ }^{23}$

\section{Conditions of Detention under a PPO}

Individuals subject to a PPO, known as "residents", are to be detained in a residence: a secure facility on prison grounds. ${ }^{24}$ Residents have the rights of individuals not subject to a PPO, except to the extent the Bill limits those rights. ${ }^{25}$ All residents are entitled to earnings from work, to vote, to access the media and to obtain a benefit. ${ }^{26}$ Residents have the right to receive visits, and written and oral communications from people outside the residence, although such visits and communications can be withheld or monitored. ${ }^{27}$ Residents also have the right to rehabilitative treatment. ${ }^{28}$ While a resident's rights can be limited, such decisions must be guided by reasonableness, proportionality and giving effect to the resident's autonomy and quality of life. ${ }^{29}$ The Bill also makes provisions for

18 Clause 13.

19 Clause 13.

20 Clause 13.

21 Clause 14.

22 Clauses 15 and 17.

23 Clause 14.

24 Clauses 3, 18 and 99.

25 Clause 24.

26 Clauses 25, 27, 30, 34.

27 Clauses 29, 31, 41-48.

28 Clause 33.

29 Clause 24. 
searches of the resident, and drug and alcohol tests. ${ }^{30}$ In strict circumstances, a resident can be placed in seclusion or restrained. ${ }^{31}$

When a resident begins their stay, the residence manager must, in consultation with the resident, assess their needs. This must take into account the cultural or religious needs of the resident, the steps to be taken to facilitate their rehabilitation or reintegration into the community and the resident's own aspirations for personal development. ${ }^{32} \mathrm{~A}$ management plan, based on this assessment, is then to be created, setting out factors including applicable treatment programmes, the nature and extent of supervision required, and a programme contributing towards the resident's release and reintegration. ${ }^{33}$

\section{Prison Detention Orders}

On application by the Chief Executive of Corrections, the Court can order an individual subject to a PPO be detained in a prison instead of a residence. ${ }^{34}$ The Court can only do so if it is satisfied the individual would pose an unacceptably high risk to himself or others if detained in a residence and all other less restrictive options have been considered and appropriate options tried. ${ }^{35}$ An individual subject to a prison detention order (PDO) is to be treated as a prisoner awaiting trial and has all the rights conferred on residents by the Bill to the extent those rights are compatible with the applicable provisions of the Corrections Act 2004. ${ }^{36}$ As with PPOs, PDOs are subject to frequent review by the review panel and the Court. ${ }^{37}$ An individual can apply to the Court for the cancellation of the order. ${ }^{38}$

\section{E Protective Supervision Orders}

If the Court is satisfied an individual no longer poses a high risk of imminent serious or sexual or violent offending, the Court must cancel the PPO and impose a protective supervision order

\footnotetext{
30 Clauses 57-58.

31 Clauses 61-62.

32 Clause 38.

33 Clause 39.

34 Clause 72.

35 Clause 72

36 Clause 73

37 Clauses 74-75.

38 Clause 76.
} 
(PSO). ${ }^{39}$ After five years, if an individual has not breached the PSO or reoffended in a serious way, the PSO can be cancelled. ${ }^{40}$

\section{CONCEPTUAL FOUNDATIONS OF THE BILL}

The drastic measures imposed by the Bill can be properly understood as reflecting two concepts: penal populism and the prevalent public attitudes towards sex offenders.

\section{A Penal Populism}

\section{The theory}

Anthony Bottoms first identified the concept of populist punitiveness in $1995 .{ }^{41}$ Now better known as penal populism, it refers to the Anglo-American trend of public support for more punitive responses to criminal offending. ${ }^{42}$ This derives from disillusionment with the criminal justice system, embodied in the perception that the rights of criminals have been prioritised over their victims and the public. ${ }^{43}$ Penal populism signifies the shift in the influences on criminal justice policy from conventional voices, such as judges and academics, to the media and law and order lobby groups, who more accurately represent public opinion. ${ }^{44}$ Responding to this, political parties propose increasingly punitive laws to appease the public, sometimes resulting in a "law and order auction" where parties outbid each other to win public support. ${ }^{45}$

In New Zealand, the late 1990s marked the start of the most recent shift towards penal populism. John Pratt points towards three key factors that influenced this trend. The first was the media, whose sensationalist reporting on criminal offending mischaracterised crime and distorted public perceptions, creating a fear crime was increasing and the public becoming more vulnerable. ${ }^{46}$ The second factor was the 1999 Law and Order Referendum, which asked whether there should be greater emphasis on the needs of victims, and minimum sentences and hard labour for all serious

39 Clause 80.

40 Clause 89.

41 Anthony E Bottoms "The philosophy and politics of punishment and sentencing" in Chris Clarkson and Rod Morgan (eds) The Politics of Sentencing Reform (Clarendon Press, Oxford, 1995).

42 Wayne Martin "Popular Punitivism - The Role of the Courts in the Development of Criminal Justice Policies" (2010) 43 Australian and New Zealand Journal of Criminology 1 at 1.

43 Sandra Grey and Katie de Roo "When the next step is capital punishment what choices do we have: Penal reform movements in the age of penal populism" (2010) 25(2) New Zealand Sociology 38 at 41.

44 John Pratt "When Penal Populism Stops: Legitimacy, Scandal and the Power to Punish in New Zealand" (2008) 41 Australian and New Zealand Journal of Criminology 364 at 364.

45 Martin, above n 42, at 12; John Pratt and Marie Clark "Penal Populism in New Zealand" (2005) 7 Punishment and Society 303 at 304.

46 Martin, above n 42, at 11; Pratt, above n 44, at 368 . 
violent offences. ${ }^{47}$ The referendum was overwhelmingly supported by 92 per cent of the public, signalling the public wanted a more punitive approach to criminal justice. The emergence of penal populism was solidified by the 2001 formation of the law and order lobby group, the Sensible Sentencing Trust (SST) ${ }^{48}$ The SST quickly rose to prominence in the media and politics on a campaign of tougher sentences for violent offenders, based on protecting and upholding victims' rights. ${ }^{49}$ It remains a popular voice today.

\section{Penal populism and the Fifth National Government}

The Fifth National Government has embraced penal populism over its last two terms in government. Prior to the 2008 Election, the crux of National's law and order policy was "no parole for the worst repeat violent offenders". ${ }^{50}$ The "two strikes, no walking" policy sought to prioritise the public's right to safety and re-characterise parole as a privilege, not a right. ${ }^{51}$ This was given effect in 2010 with the implementation of the "three strikes" regime. ${ }^{52}$ "Three strikes" was originally an SST policy. 53

The regime limits judges' discretion in sentencing repeat serious violent offenders. On a second strike, the judge must order the offender serve his or her sentence without parole and on a third strike, must impose the maximum term of imprisonment available and order that be served without parole, unless to do so would be manifestly unjust. ${ }^{54}$ This is an example of penal populism because it demonstrates National responding to, as noted in the Regulatory Impact Statement, a "public concern" about repeat violent offending. ${ }^{55}$ The scheme was designed to "enhance public confidence in the criminal justice system" by satisfying the public's appetite for harsher punishment of these kinds of offenders, and in doing so, "improve public safety". ${ }^{56}$

47 "Referenda" (24 May 2013) <www.elections.org.nz>.

48 Pratt, above n 44, at 371.

49 Grey and de Roo, above n 43, at 46.

50 New Zealand National Party Law and Order Policy: No Parole for the Worst Repeat Violent Offenders (6 October 2008) at 1.

51 New Zealand National Party, above n 50, at 1.

52 Sentencing and Parole Reform Act 2010.

53 Sensible Sentencing Trust "One Weekend Four Murders! "Three Strikes" Law Would Save Lives" (press release, 12 December 2007); Sophie Klinger "Three Strikes for New Zealand? Repeat Offenders and the Sentencing and Parole Reform Bill 2009" (2009) 15 Auckland U L Rev 248 at 248249.

54 Sentencing Act 2002, ss 86C-86D.

55 Ministry of Justice Regulatory Impact Statement: Sentencing and Parole Reform Bill 2009 (2008) at 1.

56 Ministry of Justice, above n 55, at 1-3. 
Similar rhetoric was employed prior to the 2011 Election, where National's law and order policy focused on "protecting communities" and "building a safer New Zealand". ${ }^{57}$ One of the key election promises, which manifested itself as the present Bill, was to introduce a civil detention scheme for the country's most high-risk offenders. ${ }^{58}$ This was somewhat reactionary to the scheduled upcoming release of Stewart Murray Wilson in 2012, who is a prime candidate for a PPO.

\section{Penal populism and the Bill}

As Wilson's release date approached, the New Zealand public entered into a frenzy of fear and anger, especially in Whanganui where Wilson would be released. Some members of the public expressed dissatisfaction with the law. An opinion piece in The Rotorua Daily Post accurately captured this sentiment: 59

He doesn't deserve to be let out. Unfortunately the law won't allow that. Now the community of Wanganui is suffering the impacts of a weak justice system that simply opens locked cell doors just because the sentence is over.

This quote is the epitome of penal populism. It remarks that the hallmark convention of any Western justice system, the mandatory release of an individual at the end of his or her sentence, is necessarily "weak". Unsurprisingly, there was extensive public support for retroactive legislation to keep Wilson in prison, such as the present Bill. ${ }^{60}$ This included the Whanganui District Council, who passed a resolution to lobby for retrospective legislation. ${ }^{61}$

The Council did little to assuage public fear and anger, and rather, much like the media, encouraged these feelings to increase. Despite Wilson being subject to the strictest release conditions ever imposed - 17 separate conditions including GPS monitoring - Whanganui Mayor Annette Main questioned whether this was sufficient to keep residents safe. ${ }^{62}$ The District Council resolved to ban Wilson from all Council parks and other areas and to "co-ordinate a community

57 New Zealand National Party Law and Order Policy: Protecting Communities (4 November 2011) $<$ www.national.org.nz> at 1.

58 New Zealand National Party, above n 57, at 7.

59 Kelly Makiha "Editorial: Wilson should stay in prison" The Rotorua Daily Post (online ed, Rotorua, 29 August 2012).

60 Michael Laws "Wanganui is right to resist Beast among us" The Wanganui Chronicle (online ed, Whanganui, 28 August 2012).

61 Wanganui District Council "Minutes of the Extraordinary Meeting of the Wanganui District Council held at 6.00pm on Thursday, 16 August 2012, in the Council Chamber, Municipal Office Building, 101 Guyton Street, Wanganui" (16 August 2012) <www.wanganui.govt.nz> at 3409.

62 Kieran Campbell "Mayor has fears over 'Beast' release" The New Zealand Herald (online ed, Auckland, 19 August 2012); New Zealand Parole Board Wilson - Stewart Murray - Parole hearing Under s 104(FRD) of the Parole Act 2002, above n 6. 
shunning" of him by encouraging all business owners to trespass him. ${ }^{63}$ The Council also brought a judicial review of the Parole Board's decision to release Wilson to Whanganui, but were unsuccessful. ${ }^{64}$ Meanwhile, media reporting was fixated on Wilson and included sensationalist headlines such as "The Beast Should Never Be Freed" and assertions that Whanganui had become the Beast's "new hunting ground". 65 At the first reading of the Bill, David Clendon MP suggested that the "extraordinarily irresponsible display of media reporting" and "sensationalism" concerning Wilson's release had "paved the way" for the Bill. ${ }^{66}$

However, the strongest indicator of penal populism was the response from the opposition Labour Party. Labour's justice spokesperson, Charles Chauvel, refrained from challenging the premise of the Bill. Instead, his criticism focused on the Government's delay in implementation, which had allowed one of the "targeted offenders" - Wilson - to be released. ${ }^{67}$ Given the mass public support for keeping Wilson in prison, it was politically untenable for Labour to dispute the necessity or merits of the Bill; playing into the "law and order auction", Chauvel could only criticise the Government for not acting quickly enough. This approach was continued at the first reading of the Bill where Labour MPs criticised the Government's delay and lack of consultation, but did not criticise the Bill itself. Phil Goff MP went as far as to accept that the Bill was not about punishment, but rather protecting the community. ${ }^{68}$

The political and public reaction to Wilson's release demonstrates penal populism remains a powerful force in New Zealand. In particular, it explains why the Government proposed the Bill and why it enjoys public support.

\section{B Public Attitudes Towards Sex Offenders}

\section{Common misconceptions regarding sex offenders}

The public attitude towards sex offenders is typified by a perception that sex offenders are inherently different from other offenders. ${ }^{69}$ The reason for this is that sex offences create a moral

63 Wanganui District Council, above n 61, at 3409. See also "Wanganui shop ban for Beast is back" Wanganui Chronicle (online ed, Wanganui, 24 August 2012).

64 Whanganui District Council v New Zealand Parole Board [2012] NZHC 2248.

65 Bernadette Courtney "The Beast should never be freed" The Dominion Post (online ed, Wellington, 18 April 2012); Laws, above n 60.

66 (17 September 2003) 693 NZPD 13441.

67 New Zealand Labour Party "New law requires careful scrutiny, not political game playing" (press release, 18 September 2012).

68 (17 September 2013) 693 NZPD 13441.

69 Brian K Payne, Richard Tewksbury and Elizabeth Ehrhardt Mustaine "Attitudes about rehabilitating sex offenders: Demographic, victimization, and community-level influences" (2010) 38 JCJ 580 at 582. 
panic, producing more public fear and anger than other crimes. ${ }^{70}$ Consequently, sex offenders are the most stigmatised offenders in society and are despised even by other criminals. ${ }^{71}$ They are seen as the worst offenders and the types of punishment sex offenders "deserve", such as registration and chemical castration, differ from other offenders. ${ }^{72}$

Moreover, there is an inclination to view all sex offenders in an essentialist manner. Evidence does not support the view sex offenders are identical - offending differs in conduct, ranging from exhibitionism to rape, and the motive for and underlying causes of offending are diverse. ${ }^{73}$ Nonetheless, sex offenders are grouped together and typically seen as predators, who prey on children or women, unknown to them, in a public place. ${ }^{74}$ This perception arises from the media portrayal of sex offenders, which is to focus on the worst instances of offending and report in a sensationalist way. ${ }^{75}$ In reality, while that type of offending does occur, the majority of sex offenders are known to their victims, as a member of family or as a friend, and the majority of offending takes place in or near to the victim's home. ${ }^{76}$

However, the most pervasive and worrying misconception is that sex offenders, as a group, are the most likely to reoffend. It is commonly believed the rate of recidivism amongst sex offenders is substantially higher than other offenders. ${ }^{77}$ Many authors have held there is no conclusive evidence supporting this view and that instead the inverse is true. ${ }^{78}$ The public belief that sex offenders are highly likely to reoffend is underscored by a perception that sex offenders cannot be cured. ${ }^{79}$ Theories have posited "sexual interests are imprinted on the brain in the same way as language"

70 Darrin L Rogers and Christopher J Ferguson "Punishment and Rehabilitation Attitudes toward Sex Offenders Versus Nonsexual Offenders" (2011) 20 Journal of Aggression, Maltreatment \& Trauma 395 at 407.

71 Payne, Tewksbury and Mustaine, above n 69, at 585; J Paul Fedoroff and Beverley Moran "Myths and misconceptions about sex offenders" (1997) 6 The Canadian Journal of Human Sexuality 263 at 263.

72 Rogers and Ferguson, above n 70, at 397.

73 Fedoroff and Moran, above n 71, at 275;

74 Payne, Tewksbury and Mustaine, above n 69, at 586; James F Quinn, Craig J Forsyth and Carla MullenQuinn "Societal reaction to sex offenders: a review of the origins and results of the myths surrounding their crimes and treatment amenability" (2004) 25 Deviant Behaviour 215 at 216 and 218.

75 Jo Thakker "Public attitudes to sex offenders in New Zealand" (2012) 18 Journal of Sexual Aggression 149 at $151-152$.

76 Martin, above n 42, at 3; Payne, Tewksbury and Mustaine, above n 69, at 586.

77 Payne, Tewksbury and Mustaine, above n 69, at 585.

78 Thakker, above n 75, at 149; Payne, Tewksbury and Mustaine, above n 69, at 585-586.

79 Quinn, Forsyth and Mullen-Quinn, above n 74, at 220. 
such that if an offender has a predilection to sexually offend, it cannot be changed. ${ }^{80}$ This has fostered a public attitude that treatment and rehabilitation programmes are futile and resources should instead be shifted towards the incapacitation of sex offenders. ${ }^{81}$ While the efficacy of various treatment measures is yet to be properly ascertained, there is no decisive evidence sex offenders are incurable. ${ }^{82}$

\section{Application to the Bill}

Public perspectives of sex offenders are littered with myths and misconceptions. In a 2012 survey, Jo Thakker confirmed the existence of these attitudes in New Zealand. ${ }^{83}$ Thakker further reported only 10 per cent of those surveyed could identify recent legislative changes relating to sex offenders, specifically, the creation of ESOs and expanded use of preventive detention. ${ }^{84}$ These misconceptions undoubtedly contribute towards the public support for the Bill.

The primary effect of the Bill is to detain sex offenders beyond the expiration of their prison sentences. There are three reasons why the public is in favour of such a scheme. First, society doubts the efficacy of rehabilitation programmes, and readily believes sex offenders will reoffend if released. The Bill provides a pragmatic solution to this perceived problem, by preventing the worst sex offenders from being released, perhaps forever. Secondly, the Bill indulges the public stigma surrounding sex offenders by taking a harsh approach toward them. The New Zealand public wants these "predators" to be "locked up", which the Bill easily accomplishes. Thirdly, the belief that sex offenders are different to all other offenders necessitates a separate scheme to manage them, as provided by the Bill.

The Wilson case exerts a large influence in this area. The notion all sex offenders are predators is encouraged by Wilson, who exemplifies this stereotype, having preyed on vulnerable women and their daughters, who he lured into his home under the pretext of friendship. ${ }^{85}$ Wilson's very nickname - the Beast of Blenheim - accentuates the predatory nature of his offending, as has the sensationalist media reporting on him, as documented above. The case also lends credence to the belief sex offenders are incurable. For the entirety of his 18-year sentence, Wilson refused treatment, showed no remorse and denied responsibility for his offending. ${ }^{86}$ As New Zealand's most

80 Fedoroff and Moran, above n 71, at 270.

81 Thakker, above n 75, at 160; Quinn, Forsyth and Mullen-Quinn, above n 74, at 218.

82 Thakker, above n 75, at 160.

83 Thakker, above n 75.

84 Thakker, above n 75, at 160.

$85 R v$ Wilson, above $\mathrm{n} 2$, at 1.

86 Whanganui District Council v New Zealand Parole Board, above n 64, at [27]. 
prolific sex offender, whose case has dominated news and print media, Wilson has come to be the public face of sex offenders in the country. Given the pervasiveness of Wilson's case, it is unsurprising the public supports the present Bill.

\section{CONSISTENCY WITH NZBORA}

Conceptual understanding aside, it is important to analyse the practical effect of the Bill. The Bill imposes further detention on offenders after the expiration of their finite sentence, based on their predicted likelihood to reoffend. This very concept strikes at the heart of a number of Western legal traditions, most notably, an individual's right to liberty. For some, this concern may be lessened because the potential subjects of the Bill are sex offenders who have committed horrendous crimes. However, it is in respect of minorities, whom the majority of the population dislikes, that human rights are of greatest significance. ${ }^{87}$ The strength of a legal system is often judged by the extent to which it protects the rights of those very people and therefore, the effect of the Bill on individual rights must be assessed.

In New Zealand, that assessment must be made in the context of NZBORA. NZBORA is a statutory bill of rights, enacted with the dual purpose of affirming, protecting and promoting human rights and fundamental freedoms in New Zealand, and affirming New Zealand's commitment to the International Covenant on Civil and Political Rights (ICCPR). ${ }^{88}$ Although, NZBORA is not supreme law, the Act contains the "notion of consistency with rights", as established by the operation of s 6, which requires courts to prefer meanings of legislation consistent with NZBORA where possible. ${ }^{89}$ The Attorney-General is also required to report to Parliament, at the introduction of a Bill, if any provision appears inconsistent with NZBORA. ${ }^{90}$ New Zealand courts have often been called to determine challenges to legislation made on the basis it infringes a NZBORA right or freedom..$^{91}$

The Bill raises three obvious issues - whether detention under a PPO or PDO is arbitrary within the meaning of s 22; whether such detention imposes a retroactive penalty as prohibited per s 26(1); and whether that constitutes punishing an individual for the same offence twice (double jeopardy) per s 26(2). ${ }^{92}$ For the Bill to be NZBORA compliant, detention under it must be construed as civil

87 Fardon v Attorney-General for the State of Queensland [2004] HCA 46, (2005) 223 CLR 575 [Fardon] at [143].

88 New Zealand Bill of Rights Act 1990, long title [NZBORA].

89 Paul Rishworth "Human Rights" [2012] NZ L Rev 321 at 322.

90 New Zealand Bill of Rights Act 1990, s 7.

91 For example: $R$ v Poumako [2000] 2 NZLR 695 (CA); Hansen $v$ R [2007] NZSC 7, [2007] 3 NZLR 1; Belcher v Chief Executive of the Department of Corrections [2007] 1 NZLR 507 (CA) [Belcher].

92 New Zealand Bill of Rights Act 1990, ss 22 and 26. 
committal, rather than a form of punishment. If it is punishment, then the detention will necessarily be arbitrary, impose a retroactive penalty and punish an individual for the same crime twice.

In March 2012, the Department of Corrections released a Regulatory Impact Statement on the Bill. ${ }^{93}$ This noted the risk PPOs could be construed as criminal, rather than civil orders, breaching the Government's obligations in NZBORA and the ICCPR. ${ }^{94}$ Nevertheless, Corrections recommended the scheme as the best of five options, including strengthening the ESO regime and creating a new continuing detention scheme. ${ }^{95}$

After the Bill's introduction, the Government maintained PPOs were a form of civil detention. This focused on the purpose of the Bill, which is public protection, rather than punishment. ${ }^{96}$ Specifically, because the Bill provided for detention in a civil detention facility and allowed individuals a high degree of autonomy, the Government argued it appropriately balanced the competing rights at stake. ${ }^{97}$

In October 2012, the Attorney-General issued a statement explaining why, in his opinion, the Bill was consistent with NZBORA. ${ }^{98}$ This unusual decision is the inverse of the NZBORA s 7 duty and occurs rarely, for example when former Attorney-General Margaret Wilson made public her reasons for deeming the Foreshore and Seabed Bill 2004 to be NZBORA compliant. ${ }^{99} \mathrm{Mr}$ Finlayson correctly held consistency with ss 22 and 26 of NZBORA depended on whether PPOs imposed a further penal sentence or were permissible civil committal. ${ }^{100}$ He concluded the "distinct provisions at each of the stages of the making, administration and withdrawal of detention orders ... are characteristic of a committal, rather than a penal, regime". ${ }^{101}$ This was informed by the decision in Belcher $v$ Chief Executive of the Department of Corrections (Belcher), which he regarded as the leading case on the distinction between penal and civil measures. ${ }^{102}$

93 Department of Corrections Regulatory Impact Statement: Management of High Risk Sexual and Violent Offenders at End of Sentence (20 March 2012) at 20.

94 Department of Corrections, above n 93, at 20.

95 Department of Corrections, above n 93, at 10-13.

96 Judith Collins "New orders to deal with highest risk offenders" (press release, 18 September 2012); New Zealand Government, above n 9, at 4; (17 September 2013) 693 NZPD 13441.

97 New Zealand Government, above n 9, at 4; (17 September 2013) 693 NZPD 13441.

98 Finlayson, above $\mathrm{n} 9$.

99 New Zealand Bill of Rights Act 1990, s 7; Margaret Wilson Foreshore and Seabed Bill (6 May 2004).

100 Finlayson, above n 9, at [18].

101 At [27].

102 Belcher, above n 91; Finlayson, above n 9, at [19]. 
The discussion will now move to the primary purpose of analysing the validity of the AttorneyGeneral's claim that PPOs are a form of civil committal and NZBORA compliant. The decision in Belcher will be considered, as well as case law from the United States and Australia.

\section{IS POST-SENTENCE DETENTION CIVIL OR PENAL IN NATURE?}

The essential question in determining whether the Bill is compliant with NZBORA is whether the detention imposed under the Bill is civil or penal in nature. The first consideration must be the decision in Belcher, which was the primary basis for the Attorney-General's argument that such detention was civil.

\section{A Belcher v Chief Executive of the Department of Corrections}

Belcher is a decision of the New Zealand Court of Appeal, heard by five permanent members of the Court. The case concerned an appeal brought by Joseph Belcher in respect of an ESO imposed on him. Belcher challenged the ESO regime based on its alleged inconsistency with ss 22 and 26 of NZBORA. ${ }^{103}$ The Court resolved this question by considering whether an ESO amounted to punishment and unanimously held that it did. ${ }^{104}$ William Young P, giving the reasons of the Court, identified a number of factors supporting this conclusion. ${ }^{105}$ First, the event triggering an ESO was a criminal conviction and eligibility depended on an application before an offender's sentence expired or while they were subject to release conditions. ${ }^{106}$ Secondly, the consequences of an ESO were "in effect a subset of the sanctions which can be imposed on offenders", including up to 12 months' home detention. ${ }^{107}$ Ultimately, it was thought the "imposition through the criminal justice system of significant restrictions (including detention) on offenders in response to criminal behaviour" amounted to punishment. ${ }^{108}$

The Attorney-General observed some of the Belcher factors applied to PPOs. Detention under the Bill has a strong link to prior offending: it is also triggered by a criminal conviction and the order must be applied for while an individual is nearing release or subject to an ESO. ${ }^{109}$ The restrictions the Bill imposes on an individual's liberty are more extreme than ESOs and include

103 Belcher, above n 91, at [24] and [27].

104 At [35]-[36] and [49].

105 At [47].

106 At [47].

107 At [47].

108 At [49].

109 Finlayson, above n 9, at [26.1] and [26.2]. 
"prison-like" conditions, such as seclusion and restraint. ${ }^{110}$ An individual is detained either in a residence on prison grounds, or as a last resort, in prison. ${ }^{111}$

While these factors suggest the Bill can be construed as penal, Mr Finlayson considered other provisions negated this. First, the requirement an individual "exhibits a severe disturbance in behavioural functioning" distinguishes it from ESOs and brings it in line with civil committal regimes. ${ }^{112}$ Secondly, the prison-like conditions of a PPO are mitigated by giving effect to the autonomy and quality of life of the individual. ${ }^{113}$ Thirdly, the making of a PPO is "distinct from the penal and parole system" unlike ESOs, which are made by the court that imposed the sentence of imprisonment that triggered eligibility for an ESO. ${ }^{114}$ While the Attorney-General was correct in asserting the significance of the separation of the making PPOs from the penal system, his other two arguments are not as certain and require further attention.

\section{B Case Law from Comparable Jurisdictions}

While the decision in Belcher provides a starting point for analysing the Attorney-General's statement, there is a wealth of case law from other jurisdictions to be considered. The United States and Australia are especially relevant as both have post-sentence detention regimes for sex offenders, which raise similar human rights issues. National courts in both countries, and the Human Rights Committee of the United Nations (UNHRC), have adjudicated on the human rights consistency of the schemes. In the absence of any direct New Zealand authority, these decisions provide valuable guidance. Before these decisions are taken into account, the background to the legislative schemes will be explained.

\section{The United States}

The United States has a long history of civil committal for recidivist sex offenders, dating back to the 1930s. ${ }^{115}$ The current schemes were developed in the 1990s and focus on sex offenders seen as too dangerous to release. ${ }^{116}$ Washington was the first state to enact such legislation in $1990,{ }^{117}$ which sparked a wave of similar legislation across various states. Presently, 20 states have some

110 At [26.3].

111 At [26.3].

112 At [27.1].

113 At [27.2.1]-[27.2.3].

114 At [27.1]; Belcher, above n 91, at [7] at [47].

115 Eric Janus "Civil commitment as social control: managing the risk of sexual violence" in Mark Brown and John Pratt (eds) Dangerous Offenders: Punishment and Social Order (Routledge, New York, 2000) 71 at $71-73$.

116 Janus "Civil commitment as social control", above n 115, at 71.

117 Wash Rev Code § 71.09 . 
form of post-sentence detention for sex offenders and in 2006 a federal detention programme was created. ${ }^{118}$

In Kansas v Hendricks (Hendricks), the Supreme Court held by a majority of 5-4 that such laws were constitutional as a form of civil committal. ${ }^{119}$ The decision concerned the Sexually Violent Predators Act (SVPA) enacted by Kansas in 1994, which enabled indefinite detention of sex offenders likely to engage in "repeat acts of sexual violence" because of a "mental abnormality" or "personality disorder". ${ }^{120}$ Leroy Hendricks argued the Act was unconstitutional on three grounds it breached his "substantive" due process rights (right to liberty), amounted to double jeopardy and was ex post facto (retrospective) legislation. ${ }^{121}$ Thomas $\mathrm{J}$ gave the opinion for the majority, rejecting all three arguments. The minority, in an opinion given by Breyer J, dissented with regard to the latter two arguments.

Under the SVPA, an individual found be a sexually violent predator by the court, is placed in the custody of the Secretary of Social and Rehabilitative Services for "control, care and treatment" until they no longer pose any danger. ${ }^{122}$ Such individuals may be detained by the Department of Corrections under an interagency agreement, meaning detention takes place in prison, although individuals are to be housed and managed separately from regular offenders. ${ }^{123}$ In practice, detention takes place in the psychiatric wing of a prison hospital, where individuals detained under the SVPA are treated in the same way as ordinary prisoners. ${ }^{124}$

\section{Australia}

Post-sentence detention legislation for sex offenders began in Australia in 2003 when Queensland passed the Dangerous Prisoners (Sexual Offenders) Act (DPSOA). ${ }^{125}$ Similar legislation has been passed in New South Wales, ${ }^{126}$ Victoria ${ }^{127}$ and Western Australia. ${ }^{128}$ The

118 Tamara Rice Lave "Controlling Sexually Violent Predators: Continued Incarceration at What Cost?" (2011) 14 New Crim L Rev 213 at 215; Adam Walsh Child Protection and Safety Act 42 USC § 16901.

119 Kansas $v$ Hendricks 521 US 346 (1997).

120 Kan Stat Ann § 59-29a01.

121 Kansas $v$ Hendricks, above n 119, at 350.

122 Kan Stat Ann § 59-29a07.

123 Kan Stat Ann § 59-29a07(a).

124 Kansas v Hendricks, above n 119, at 379.

125 Dangerous Prisoners (Sexual Offenders) Act 2003 (Qld).

126 Crimes (Serious Sex Offenders) Act 2006 (NSW).

127 Serious Sex Offenders (Detention and Supervision) Act 2009 (Vic).

128 Dangerous Sexual Offenders Act 2006 (WA). 
DPSOA enables the court to order the indefinite detention of a prisoner considered a serious danger to the community. ${ }^{129}$ There must be an unacceptable risk the prisoner will commit a serious sexual offence if released, as demonstrated by evidence, to a high degree of probability. ${ }^{130}$ While subject to an order of indefinite detention, an individual is detained in prison and retains the status of a prisoner, even though their sentence has expired. ${ }^{131}$

The constitutionality of the DPSOA was challenged in Fardon $v$ Attorney-General for the State of Queensland (Fardon) in the High Court of Australia. ${ }^{132}$ Robert Fardon, detained under the DPSOA, argued the Act was unconstitutional because the function it conferred on the Supreme Court was incompatible with the Supreme Court's position under the Constitution. ${ }^{133}$ The case turned on that narrow point and the majority of the Court, Kirby $\mathrm{J}$ dissenting, upheld the constitutionality of the DPSOA. In his dissent, Kirby J discussed the human rights implications of the Act and convincingly argued it was invalid. The crux of his argument was that because the DPSOA allowed for continuing prison detention, it was clearly punitive and amounted to retroactively imposed double punishment. ${ }^{134}$

In 2007, Fardon and Kenneth Tillman, an individual detained under the New South Wales equivalent legislation, submitted communications to the UNHRC under the Optional Protocol to the ICCPR. ${ }^{135}$ They alleged Australia had breached their right to be free from arbitrary detention and double jeopardy. ${ }^{136}$ The UNHRC found the continuing detention schemes breached these rights, as well as the prohibition of retroactive penalties. ${ }^{137}$

129 Dangerous Prisoners (Sexual Offenders) Act 2003 (Qld), s 13.

130 Dangerous Prisoners (Sexual Offenders) Act 2003 (Qld), s 13.

131 Dangerous Prisoners (Sexual Offenders) Act 2003 (Qld), s 14(1).

132 Fardon, above n 87.

133 At [1].

134 At [156], [162], [165], [182] and [185].

135 United Nations Human Rights Committee Fardon v Australia Communication No 1629/2007 UN Doc CCPR/C/98/D/1629/2007 (2010) [Fardon Communication]; United Nations Human Rights Committee Tillman v Australia Communication No 1635/2007 UN Doc CCPR/C/98/D/1635/2007 (2010) [Tillman Communication].

136 International Covenant on Civil and Political Rights 999 UNTS 171 (opened for signature 16 December 1966, entered into force 23 March 1976), arts 9 and 14 [ICCPR]; Fardon Communication, above n 135, at [1]; Tillman Communication, above n 135, at [1].

137 ICCPR, above n 134, art 15; Fardon Communication, above n 135, at [7.4]. 


\section{MENTAL REQUIREMENT FOR CIVIL COMMITTAL}

Returning to the Attorney-General's statement, the first issue for consideration is the whether the Bill establishes a form of civil committal. The Attorney-General believed that it did because of the cl 13 requirement that an individual exhibit a "severe disturbance in behavioural functioning". This is based on the traditional understanding of civil committal, which applies to individuals with some form of mental impairment.

\section{A New Zealand}

In New Zealand, civil committal of those with a mental disorder is provided for in the Mental Health (Compulsory Assessment and Treatment) Act 1992 (Mental Health Act). Mental disorder is defined as: ${ }^{138}$

An abnormal state of mind (whether of a continuous or an intermittent nature), characterised by delusions, or by disorders of mood or perception or volition or cognition, of such a degree that it-

(a) poses a serious danger to the health or safety of that person or others; or

(b) seriously diminishes the capacity of that person to take care of himself or herself.

Case law has indicated the definition purposefully avoids requiring a clinically diagnosed mental illness. ${ }^{139}$

The phrase "mental disorder" is not mentioned in the Bill. In fact, a Cabinet Paper on the Bill states those detained under the Bill are unlikely to satisfy the requirements for civil committal under the Mental Health Act. ${ }^{140}$ This is an explicit recognition that the individuals whom PPOs are targeted at fall outside the existing scope of civil committal in New Zealand. This acknowledgment is of crucial importance for the Bill. If the Bill is to be construed as civil, it means the threshold for civil committal in New Zealand is necessarily being widened.

\section{$B$ The United States}

This issue was also confronted in Hendricks, where a "mental abnormality or personality disorder" was required by the SVPA. Hendricks argued the SVPA was invalid because it lowered the traditional threshold for civil committal - a mental illness. ${ }^{141}$ Thomas J recognised a finding of dangerousness alone was insufficient for civil committal; an "additional factor" such as mental

138 Mental Health (Compulsory Assessment and Treatment) Act 1992, s 2.

139 Waitemata Health v Attorney-General [2001] NZFLR 1122 (CA); Ministry of Health Guidelines to the Mental Health (Compulsory Assessment and Treatment) Act 1992 (November 2012) at [1.1].

140 Cabinet Paper "Public Protection Orders - Establishing A Civil Detention Regime" (20 March 2012 ) at 8.

141 Kansas v Hendricks, above n 119, at 358-359. 
illness was required. ${ }^{142}$ This served the purpose of limiting committal to individuals "who suffer from a volitional impairment rendering them dangerous beyond their control". ${ }^{143}$ In the majority's opinion, a "mental abnormality" or "personality disorder" sufficed as the "additional factor", because it would mean offenders were unable to control their dangerousness. ${ }^{144}$ The minority concurred with the majority on this point, ${ }^{145}$ which was later affirmed in Kansas v Crane. ${ }^{146}$

This was problematic because the Kansas Legislature expressly acknowledged the SVPA applied to sex offenders "who do not have a mental disease or defect that renders them appropriate for involuntary treatment" under Kansas' general civil committal statute. ${ }^{147}$ Hendricks too, then, lowers the standard for civil committal.

\section{Is the Threshold Too Low?}

The decision in Hendricks has been the subject of intense scrutiny. Many mental health professionals believe it unacceptably widens the threshold for civil committal. ${ }^{148}$ Critics observe that while the meaning of mental illness is clear, with definitions, guidelines and evidentiary standards, "mental abnormality" is a legislative construct lacking the same characteristics. ${ }^{149}$ Kennedy J, concurring with the majority in Hendricks, recognised this concern, stating the SPVA would be unconstitutional "if it were shown that mental abnormality is too imprecise a category to offer a solid basis for concluding that civil detention is justified". ${ }^{150}$

The Bill is vulnerable to the same critique. While a mental illness is not required for civil committal in New Zealand, the Mental Health Act is clear as to what level of mental disorder is needed. This is a lower threshold than that applicable in the United States, and the Bill further reduces it. This casts the net for civil commitment far too widely. Research demonstrates the majority of prisoners suffer from some sort of antisocial personality disorder and would satisfy

142 At 358 .

143 At 358.

144 At 358 .

145 At 373 .

146 Kansas v Crane 534 US 407 (2002).

147 Kan Stat Ann § 59-29a01.

148 Bernadette McSherry and Patrick Keyzer Sex Offenders and Preventive Detention: Politics, Policy and Practice (The Federated Press, Sydney, 2009) at 61.

149 Kimberly A Dorsett "Kansas $v$ Hendricks: Marking the Beginning of a Dangerous New Era in Civil Commitment," (1998) 48 DePaul L Rev 113 at 140.

150 At 373. 
requirements such as a "mental abnormality" or "severe disturbance in behavioural functioning". ${ }^{151}$ For example, a New Zealand study revealed 59.6 per cent of prisoners had at least one verified personality disorder diagnosis. ${ }^{152}$ This suggests a large percentage of the prison population could be caught by the lower mental standard required by the Bill. This is inherently problematic when the purpose of the requirement is to limit those eligible for civil committal and prevent individuals being detained on dangerousness alone. ${ }^{153}$

This suggests the Attorney-General and the Court in Hendricks are wrong to conclude something less than the existing standard suffices to make the respective schemes forms of civil committal. If that is the case, it becomes easy to construe the schemes as merely a tool for the legislature to detain those it identifies as dangerous. Breyer $\mathrm{J}$, dissenting in Hendricks, noted this concern. ${ }^{154}$ This is troubling because dangerousness is a tenuous basis for imprisonment, being based on predictions of future offending, which may never eventuate. Kirby J, dissenting in Fardon, regarded predictions of dangerousness as unreliable because they were often over predicted by psychiatrists and ultimately, only an "educated guess". ${ }^{155}$ The UNHRC echoed this sentiment, stating dangerousness is an "inherently problematic" concept for similar reasons. ${ }^{156}$

\section{Concluding Remarks}

The mental requirement in $\mathrm{cl} 13$ does not conclusively establish the Bill is a form of civil committal, contrary to the Attorney-General's assertion. However, it is important that the Bill, like the SVPA, includes some form of mental requirement. This contrasts with the schemes operating in Australia. For example, Queensland's DPSOA, while requiring psychiatric evidence to be considered, does not require a finding of any sort of mental condition. ${ }^{157}$ Kirby $\mathrm{J}$ was especially concerned by this major departure from the established principles of civil commitment in Australia and accordingly rejected the DPSOA as a form of civil committal. ${ }^{158}$ The Attorney-General's

151 John Kip Cornwell "Sex Offenders and the Supreme Court" in Bruce J Winick and John La Fond (ed) Protecting Society from Sexually Dangerous Offenders: Law, Justice and Therapy (American Psychological Association, Washington DC, 2002) at 202.

152 Department of Corrections The National Study of Psychiatric Morbidity in New Zealand Prisons: An Investigation of the Prevalence of Psychiatric Disorders amongst New Zealand Inmates (1999)at 63.

153 Cynthia A King "Fighting the Devil We Don't Know: Kansas v Hendricks, a Case Study Exploring the Civilization of Criminal Punishment and its Ineffectiveness in Preventing Child Abuse" (1999) 40 Wm \& Mary L Rev 1427 at 1446.

154 Kansas v Hendricks, above n 119, at 384.

155 At [124]-[125].

156 Fardon Communication, above n 135, at [7.4].

157 Dangerous Prisoners (Sexual Offenders) Act 2003 (Qld), ss 11-12.

158 Fardon, above n 87, at [148], [162] and [168]-[169]. 
argument the Bill is civil in nature, is at least in that respect, more credible than its Australian counterparts.

\section{DETENTION AND IMPRISONMENT}

The Attorney-General's second reason in deciding detention under the Bill was civil was that its provisions give meaningful effect to the autonomy and quality of life of individuals. This nuanced argument contradicts the more obvious response that detention in a prison or a secure facility on prison grounds is the classic example of punishment, as suggested by theories of punishment.

\section{A Theories of Punishment}

The standard definition of punishment, developed by HLA Hart comprises five elements. ${ }^{159}$ Specifically, punishment: ${ }^{160}$

(a) must involve pain or other consequences normally considered unpleasant;

(b) must be for an offence against legal rules;

(c) must be of an actual or supposed offender for his offence;

(d) must be intentionally administered by human beings other than the offender; and

(e) must be imposed and administered by an authority constituted by a legal system against which the offence is committed.

Joel Feinberg accepted this definition, adding the qualification that punishment must serve an expressive function. ${ }^{161}$ Feinberg's thesis was that, in addition to involving "hard treatment" ("pain or other consequences"), punishment expresses resentment, indignation and the judgements of disapproval and reprobation. ${ }^{162}$ According to Feinberg, these elements of punishment need not be distinct. The "hard treatment" an offender is subjected to may also express disapproval. ${ }^{163}$ In particular, Feinberg considered that certain forms of hard treatment, such as incarceration, have become entrenched as typical expressions of reprobation. ${ }^{164}$ Applied to the Bill, detention in a secure facility on prison grounds or in prison satisfies the formalistic and expressive requirements of

159 HLA Hart "The Presidential Address: Prolegomenon to the Principles of Punishment" (1959) 60 Proceedings of the Aristotelian Society 1 at 4; Michael Davis "Punishment Theory's Golden Half Century: A Survey of Developments from (about) 1957 to 2007" (2009) 13 J Ethics 73 at 75.

160 Hart, above n 159, at 4.

161 Joel Feinberg "The Expressive Function of Punishment" in Anthony Duff and David Garland (eds) A Reader on Punishment (Oxford University Press, Oxford, 1994) 73 at 73-74.

162 Feinberg, above n 161, at 74.

163 Feinberg, above n 161, at 76.

164 Feinberg, above n 161, at 76 and 84. 
punishment. Thus, according to theory, the Bill and other post-sentence detention schemes are straightforward examples of punishment.

Courts have attempted to circumvent this issue by focusing on the purpose of detention. While incapacitation is a common purpose of civil committal and imprisonment, retribution and deterrence are purposes of only imprisonment. Therefore, in order to conceive the schemes as civil committal, courts have held that retribution and deterrence are not applicable purposes.

According to retributive theorists, the foundation for imposing punishment is that the offender deserves to be punished because they have committed a crime. ${ }^{165}$ This includes an element of proportionality - offenders should be punished according to their culpability and the seriousness of their offence. ${ }^{166}$ In Hendricks, the majority found no retributive purpose in the SVPA because it did "not affix culpability for prior criminal conduct". ${ }^{167}$ Instead, the prior offending was only evidence used to support a finding of dangerousness or the existence of mental abnormality or personality disorder. ${ }^{168}$ Another reason the schemes are not retributive, as per Callinan and Heydon JJ in Fardon, is that their purpose is not to impose detention on individuals who deserve punishment, but rather to protect the public. ${ }^{169}$

Deterrence encompasses the idea that punishment has a crime-preventive consequence, ${ }^{170}$ by acting as a disincentive for criminal offending. ${ }^{171}$ This applies at a specific level, in terms of the individual offender, and at a general level, in terms of other would-be offenders. ${ }^{172}$ In Hendricks, the Court rejected any deterrent purpose, because the Act applied to offenders with no control over their actions (due to a mental abnormality or a personality disorder), who would not be deterred by the threat of confinement. ${ }^{173}$ This argument is plausible; theory posits deterrence is necessarily limited by the extent to which the targeted offender or would-be offenders consider the risk of

165 Michael S Moore "The Moral Worth of Retribution" in Andrew von Hirsch and Andrew Ashworth (eds) Principled Sentencing: Readings on Theory and Policy (Hart Publishing, Oxford, 1998) 150 at 150.

166 Andrew von Hirsch "Proportionate Sentences: A Desert Perspective" in Andrew von Hirsch and Andrew Ashworth (eds) Principled Sentencing: Readings on Theory and Policy (Hart Publishing, Oxford, 1998) 168 at 170 .

167 At 362 .

168 At 362

169 At 654

170 Andrew von Hirsch and Andrew Ashworth (eds) Principled Sentencing: Readings on Theory and Policy (2nd ed, Hart Publishing, Oxford, 1998) at 44.

171 Andrew Ashworth Principles of Criminal Law (6th ed, Oxford University Press, Oxford, 2009) at 16.

172 Brian Bix Jurisprudence: Theory and Context (Westview Press, Colorado, 1996) at 127.

173 At 362-363. 
punishment rationally. ${ }^{174}$ In particular, deterrence is ineffective where the targeted offenders suffer from a mental condition that affects their ability to obey the law. ${ }^{175}$

In Hendricks, having rejected the applicability of the "two primary objectives of criminal punishment", the majority deferred to the Kansas Legislature's framing of the SVPA as civil. ${ }^{176}$ This approach can similarly be applied to the Bill. Clauses 4 and 5 explicitly disclaim any retributive purpose and for the reasons enunciated by the majority in Hendricks, a deterrent purpose is inapplicable. Therefore, there is a case for deferring to the Government's framing of the Bill as civil.

However, the decision in Belcher precludes this analysis. In finding ESOs to be a form of punishment, the Court held it was not "decisive that the aim of the ESO scheme is to reduce offending ... as opposed to the direct sanctioning of the offender for the purposes of denunciation, deterrence or holding to account". ${ }^{177}$ In fact, many criminal law sanctions, such as preventive detention and supervision, have a similar aim but are still considered penalties. ${ }^{178}$ This conclusion is supported by various academics including Patrick Keyzer, who unequivocally states "[p]rison does not stop being punitive because the parliaments or courts characterise the purpose of imprisonment as non-punitive". ${ }^{179}$ Therefore, in New Zealand, an argument the Bill is civil because its purpose is protective or non-punitive is unlikely to succeed.

This approach is superior to that in Hendricks. The majority's decision to uphold the SVPA as civil, based on the purpose of detention being non-punitive, was flawed. It ignores the larger issue at stake - that an individual is being detained in a prison hospital, with other prisoners, potentially indefinitely, after his or her sentence has expired. It is hollow to contend this is not punitive, solely because its alleged purpose is not retribution or deterrence. If the detention amounts to punishment in substance, its purpose should not matter. Furthermore, the finding the SVPA had no retributive purpose was artificial at best. It is plausible it does serve a retributive purpose - to imprison sex offenders who "deserve" to be "locked up" based on their past crimes. This punitive intent was certainly reflected in statements of the Attorney General for Kansas who stated, "we cannot open our prison doors and let these animals back into the community". ${ }^{180}$ The majority should have taken

\footnotetext{
174 Von Hirsch and Ashworth, above n 170, at 49.
}

175 Richard S Frase "Punishment Purposes" (2005) Stan L Rev 67 at 71.

176 Kansas v Hendricks, above n 119, at 361-362.

177 At [48].

178 Belcher, above n 91, at [48].

179 Patrick Keyzer "The "Preventive Detention" of Serious Sex Offenders: Further Consideration of the International Human Rights Dimensions" (2009) 17 Psychiatry Psychol \& L 262 at 264.

180 Thomas J Weilert "Thoughts on the Cost of Freedom" (1997) 46 Kan L Rev 17 at 21. 
a more rigorous approach, such as the Court in Belcher, rather than deferring to the Kansas legislature's framing of the SVPA as civil.

\section{$B$ Substantive Analysis of Detention under the Bill}

Breyer J, for the Hendricks minority, took this approach and focused on how the SVPA operated in practice. He noted detention under the SVPA was similar to imprisonment; it was "secure confinement ... against one's will". ${ }^{181}$ This, combined with the location of detention, in a prison, meant it could be construed as punishment. ${ }^{182}$ The Attorney-General correctly followed this approach, but reached the opposite conclusion, holding that the "prison-like conditions" of detention under the Bill, which appeared punitive in substance, were displaced by the focus on the individual's autonomy and rights. ${ }^{183}$

To evaluate this argument it is important to distinguish between PPOs and PDOs, the AttorneyGeneral's argument being more persuasive with regards to the former. PPO detainees will live in a residence on prison grounds, completely separate from existing prisoners. They are entitled to rights prisoners are not, such as the right to vote and obtain a benefit. Individuals are to have as much autonomy and quality of life as possible, while providing for security concerns. The combination of these factors suggests that residents will be able to have a more normal, functioning daily life than prisoners.

However, as noted by the New Zealand Law Society in its submission to the Justice and Electoral Select Committee, "[m]any aspects of civil liberty have been removed" from residents. ${ }^{184}$ Further, the Aotearoa Human Rights Lawyers Association noted that residences are situated on prison grounds and residents are, like prisoners, in the custody of the Chief Executive of the Department of Corrections. ${ }^{185}$ These points led both organisations to conclude that PPOs were penal in nature. This is a balanced point and the argument remains that detention under a PPO is different enough to prison detention so as not to be considered a form of punishment. For example, the Law Society opined that detention would be non-punitive if "living conditions" are "significantly better than those in prisons". ${ }^{186}$ For the reasons given above, it is likely that

181 At 379.

182 At 379.

183 Finlayson, above n 9, at [26.3] and [27.2].

184 New Zealand Law Society "Submission to the Justice and Electoral Committee on the Public Safety (Public Protection Orders) Bill" at [13].

185 Aotearoa Human Rights Lawyers Association "Submission to the Justice and Electoral Committee on the Public Safety (Public Protection Orders) Bill" at [2.6.2.4].

186 New Zealand Law Society, above n 184, at [18]. 
conditions will be better than those in prisons and as such, detention under a PPO can be construed as non-punitive.

However, the same cannot be said with regards to PDOs. Although only imposed as a last resort, PDOs require detention in a prison. Individuals are to be treated as a prisoner awaiting trial (a remand prisoner), with the same rights entitlements as those subject to a PPO, to the extent that the rights are consistent with the Corrections Act 2004. Many of the rights entitlements of those subject to a PPO have an equivalent provision in the Corrections Act: there are provisions for individuals to work; ${ }^{187}$ have reasonable access to the news; ${ }^{188}$ receive visitors; ${ }^{189}$ and receive mail and make telephone calls, ${ }^{190}$ subject to some degree of monitoring. ${ }^{191}$ However, the Corrections Act also imposes a variety of restrictions, such that the rights it confers are not as meaningful as in the Bill. ${ }^{192}$ The focus is not on the autonomy and quality of life of the individual, but rather on ensuring prisoners' minimum entitlements are met. ${ }^{193}$ Most fundamentally, an individual subject to a PDO is kept within the confines of a prison building and their day-to-day life mirrors that of a regular prisoner.

The distinguishing status of individuals subject to PDOs as remand, rather than sentenced, prisoners is of little practical difference. There is no distinction in the rights entitlement between classes of prisoners, barring that remand prisoners are allowed to vote. ${ }^{194}$ However, remand prisoners are housed separately from sentenced prisoners and are generally permitted to wear their own clothing while in prison. ${ }^{195}$ These differences are negligible. Wearing different clothing or being housed in a separate area within a prison does not change the fact such individuals live under the same conditions as prisoners, imposed on them by the same administration. Their liberty is restrained in the exact same way. Therefore, the detention of individuals under a PDO can be construed as imprisonment and punitive in nature. This is consistent with the findings of the UNHRC which emphasise that "prison is penal in character". ${ }^{196}$

\footnotetext{
187 Corrections Act 2004, s 66.

188 Corrections Act 2004, s 78.

189 Corrections Act 2004, s 73.

190 Corrections Act 2004, s 76-77.
}

191 Corrections Act 2004, ss 106-108 and s 111-113.

192 Section 69.

193 Corrections Act 2004, s 69.

194 Electoral Act 1993, s 81.

195 Department of Corrections "Arriving in prison" < www.corrections.govt.nz>

196 Fardon Communication, above n 135, at [7.3]. 


\section{IMPLICATIONS FOR THE BILL}

It is clear the Bill has implications for compliance with human rights standards. There are two particular issues - what mental requirement is needed for civil committal, and whether detention under the Bill is, in substance, punishment.

It could be argued the Bill is an example of penal populism, where the Government, sensing the outrage in response to Wilson's pending release, acted to pass a Bill it knew would garner public support. The public's attitude towards offenders has become increasingly punitive, and the Nationalled Government has responded to this in the past, both in its electoral campaigns and in the "three strikes" regime. This suggestion is also strengthened by the common misconceptions the public has regarding sex offenders, such as their inability to be rehabilitated. If this were the case, the Bill would be a worrying example of the tyranny of the majority, perpetuated over the unpopular minority of sex offenders, with little principled basis.

However, it would be wrong to characterise the Bill in such a way. Its provisions plainly demonstrate the Government has engaged with NZBORA concerns and tried to reduce inconsistencies. The inclusion of some form of mental requirement to trigger the application of the Bill demonstrates New Zealand has learnt from the Australian equivalent statutes, which contain no such requirement. Even though the Bill widens the threshold for civil committal by deviating from the standard in the Mental Health Act, it does not so as dramatically as the various state schemes in the United States. For example, in Kansas, the SVPA lowers the standard for civil committal from a mental illness to a "mental abnormality or personality disorder" and has been subject to much criticism on this basis. ${ }^{197}$

The Government must also be given credit for developing a completely separate scheme of detention for PPOs. This ensures such detention is not substantively the same as imprisonment. However, questions remain with respect to whether PDOs are substantively different from imprisonment; this paper suggests they are not. PDOs are closer to the United States and Australian schemes where those detained are treated the same as existing prisoners. A redeeming factor for the Bill is that PDOs are not envisaged as the norm and only imposed as a last resort, when all other less restrictive options have been considered or tried. ${ }^{198}$ This contrasts to the United States and Australian schemes, which do not require the consideration of less restrictive alternatives. Breyer J, dissenting in Hendricks, criticised the SVPA for not requiring consideration of post-release

197 See for example McSherry and Keyzer, above n 148, at 61.

198 Public Safety Bill, cl 72. 
supervision or halfway houses. ${ }^{199}$ Likewise, the UNHRC held Australia should have demonstrated why "less intrusive" means than continuing imprisonment were insufficient to manage Fardon. ${ }^{200}$

A regime providing for the post-sentence detention of sex offenders could be far more offensive to human rights than the contemplated Bill. It is hard to envisage a less restrictive scheme that achieves the same purpose as the Bill. The Australian equivalent schemes with no mental requirement and continued prison detention embody the worst possible option. The callousness of the Australian attitude was demonstrated by that Government's decision to ignore the UNHRC's findings that it had breached multiple arts of the ICCPR. ${ }^{201}$ Today, Fardon continues to be detained in prison. While there are some concerns with the New Zealand Bill, they do not demonstrate such a blatant disregard for human rights.

\section{CONCLUSION}

The purpose of this paper was to analyse the validity of the Attorney-General's claim that the Public Safety (Public Protection Order) Bill is consistent with human rights. At first glance, the concept of the Bill - the detention of sex-offenders beyond their finite sentences - suggested it would compromise core rights protected in NZBORA. However, on closer inspection, it is clear the Bill has been drafted to engage with and lessen these concerns. The Bill has emerged from the select committee process largely unchanged in this regard. The Attorney-General argued the Bill was a form of civil committal, and that the detention it imposed was different to imprisonment. For the most part, these arguments are correct. However, the Attorney-General's analysis could have been more thorough with regard to lowering the threshold for civil committal and the substantive effect of detention under PDOs, as discussed in this paper. On the whole, and in comparison to the schemes operating in the United States and Australia, the Bill strikes an appropriate balance between the competing interests at stake - public protection and human rights.

199 At 387.

200 Fardon Communication, above n 135, at [7.4].

201 Australian Government Response of the Australian Government to the Views of the Committee in Communication No 1635/2007 Tillman v Australia and Communication No 1629/2007 Fardon v Australia (2011) at [18]-[19]. 
